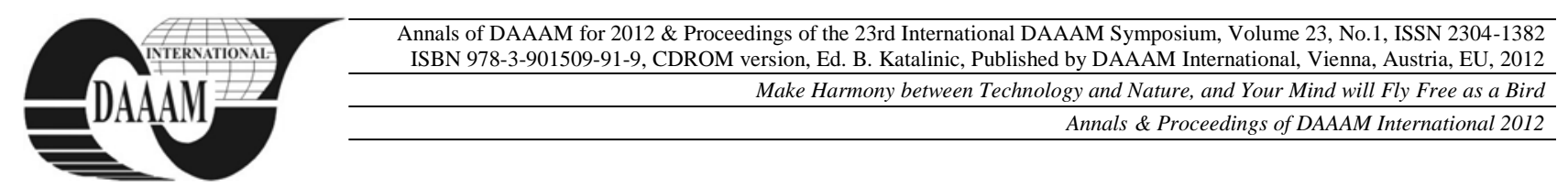

\title{
THE IMPACT OF THE ACCOUNTING INFORMATION SYSTEM USAGE ON COMPANYS' E-BUSINESS EFFICIENCY
}

\author{
SPREMIC, M[ario] \& JAKOVIC, B[ozidar]
}

\begin{abstract}
In this paper an analysis of the impact of the Accounting Information System usage on the company's ebusiness efficiency is made. The analysis is based upon the secondary data on the application of the e-business in the companies in 29 European countries, as well as on the primary data obtained by a survey on 252 Croatian companies. We conducted a relevant empiric research (using Hi-square and Levene's Test analyses) which gives the up-to-date information on the impact of Accounting Information System usage on ebusiness efficiency and made it possible not to reject the hypothesis that indeed Accounting Information System usage affects the e-business efficiency.
\end{abstract}

Keywords: Electronic business, Accounting Information System, E-business efficiency, Hi-square test, Levene's Test

\section{INTRODUCTION}

Electronic business (e-business) encompasses the electronic information exchange within the organization, as well as between the organization and the other subjects [1]. Furthermore e-business does not consist only of internet companies or sales and purchases on the web, e-business is a much broader concept which includes also the internet related technologies so as to integrate and reorganize the internal company activities, business processes and external linkages [2].

E-Business evolves rapidly and its significance grows, but also the factors that affect it change daily [3]. In today's highly competitive business environment, effective and innovative use of information systems (IS) and accompanied information and communications technology (ICT), as their integral part, e-business has the potential to transform businesses as well as to positively affect organizations performance. IS and ICT allow individuals to disseminate large volumes of information quickly and efficiently, share information with a global audience and they may be updated easily.

For example, ICTs may help create a networked structure for interconnectivity [4], service delivery [5], efficiency and effectiveness [6], interactivity [7], decentralization, transparency [8] and accountability [9].

These benefits are particularly valuable to the service industry where IS represents cornerstone of successful ebusiness implementation. Main objective of this paper is to stress the importance of IS in implementation of ebusiness concept, namely through conducting business transactions which are happening 'underneath' e-business.

\section{ACCOUNTING INFORMATION SYSTEM}

Electronic business (e-business) refers to the intensive use of IS and ICT (especially Internet technologies) in conducting business transactions and services to customers. Most organizations in all sectors of industry, commerce and government are fundamentally dependent on their (IS) and would quickly cease to function should the technology (preferably ICT) that underpins their activities ever come to halt [10]. In the pre e-business era, the potential use of IS and ICT as a competitive force in concurrent environments can differ between industries and companies, and can serve to raise different barriers to new entrants in a market, switching costs, product differentiation, access to distribution channels, improvement of price/performance relationship etc. The new business era inaugurates the information infrastructure (particularly the Internet) as a business backbone and a platform for conducting business transactions and other economic activities, making IS and ICT a key prerequisite for a successful e-business model [11].

Information systems (IS) plays very important role in modern business organizations supporting its organizational efficiency or, under certain circumstances, fostering business model innovation and change. IS can influence organization competiveness in two ways [12]:

- supporting operational efficiency (IS as a main infrastructure for the current business), or

- differentiating business through business model innovation and business process change.

In the first role IS enhance conduction of business processes in more efficient, quicker and effective way supporting cost leadership strategy. For example, reservation of flight ticket is up to seven times cheaper for the company if done via their own internet based reservation system compared to counter transactions. The cost of an e-banking transaction is up to 50 times cheaper for the bank compared to counter transaction.

It is quite obvious that transaction information system and accounting information system as their vital part plays very important role in implementing e-business concept. Also, IS may contribute towards efficiency, productivity and competitiveness improvements of both inter-organizational and intra-organizational systems [13] and successful organizations manage IS/IT function in much the same way that they manage their other strategic functions and processes. Apart from expert opinions and large number of success stories, it is necessary to find the scientific evidences on the usage of transaction and 
accounting information system in implementing ebusiness concept.

\section{RESEARCH METHODOLOGY}

Having in mind latter discussion on possible (positive) use of IS (namely accounting IS) on e-business performance we posed two research hypotheses:

H0: Usage of the Accounting Information System and the efficiency of e-business of a company are statistically independent variables.

H1: Usage of the Accounting Information System and the efficiency of e-business of a company are statistically dependent variables.

In order to examine the hypotheses statistical dependence variable usage of the Accounting Information System to the efficiency of e-business will be performed using the chi-square test.

The key objective of the research has been to examine a number of issues regarding the usage of accounting IS in e-business performance. The research instrument includes research study conducted on the sample of 1500 companies from Croatia. Data used in this paper is from the database obtained from the European Commission (ebusinessw@tch). This database contains the information collected through a survey of the company managers or company-subdivision managers. The data have been collected in 29 countries from 14.065 companies.

In order to broaden the dataset with Croatian dataset, an original empiric survey is made in Croatia. on the sample of 1500 companies (500 small companies, 500 medium sized companies and 500 large companies, according to the Croatian Chamber of Commerce classification and their company registry). After the exclusion of the incomplete submitted questionnaires, the sample for Croatia has 252 companies, on which the complete empiric survey was made. To address the research's objectives, firstly we draw a survey questionnaire to be able to collect general information about accounting IS practices during years in surveyed companies. The questionnaire was then sent to people who are responsible for decisions in area of information and communication technology in companies, for instance to somebody in the IT department or in a management position. The survey has been performed in the period from November 2011 to February 2012. and was conducted by using prescribed web-based questionnaire. The survey resulted in important responses which give us the crucial information about the growing maturity of accounting IS in e-business performance.

From various models that measure efficiency of ebusiness, in this paper we used e-business scoreboard index, which was modified to seven categories: revenue growth, business process efficiency, internal organization, cost reduction in the process of ordering, quality of products and services, quality of user support and productivity growth. The index obtained in this way can have the value from 0 to 7 . Table 1 shows descriptive statistics for the index of the efficiency of e-business by countries. The means of indices of efficiency of ebusiness vary from country to country, range from 2,65 to 5,75 (on a scale from 0 to 7 ), and the standard deviation from 1,596 to 2,864 .

\begin{tabular}{|c|c|c|c|c|c|}
\hline Country & $\mathbf{N}$ & MIN & MAX & Mean & $\begin{array}{c}\text { Std. } \\
\text { Deviation }\end{array}$ \\
\hline France & 723 &, 00 & 7,00 & 2,7566 & 2,24446 \\
\hline Germany & 761 & ,00 & 7,00 & 3,2983 & 2,16652 \\
\hline Italy & 686 & ,00 & 7,00 & 3,7114 & 2,81779 \\
\hline Poland & 672 & ,00 & 7,00 & 3,6756 & 2,52949 \\
\hline Spain & 700 & ,00 & 7,00 & 3,7100 & 2,61724 \\
\hline Great Britain & 680 & ,00 & 7,00 & 4,0265 & 2,34364 \\
\hline Austria & 373 & 00 & 7,00 & 3,2681 & 2,10809 \\
\hline Belgium & 348 & 00 & 7,00 & 3,2356 & 2,59276 \\
\hline Bulgaria & 341 & ,00 & 7,00 & 3,6833 & 2,64230 \\
\hline Cyprus & 192 & 00 & 7,00 & 4,7865 & 2,28842 \\
\hline $\begin{array}{l}\text { Czech } \\
\text { Republic }\end{array}$ & 647 & ,00 & 7,00 & 3,9212 & 2,86350 \\
\hline Denmark & 341 & ,00 & 7,00 & 4,0704 & 2,02942 \\
\hline Estonia & 266 & 00 & 7,00 & 4,6015 & 2,56372 \\
\hline Finland & 676 & 00 & 7,00 & 3,7648 & 2,23494 \\
\hline Greece & 372 &, 00 & 7,00 & 4,6022 & 2,19354 \\
\hline Hungary & 662 & 00 & 7,00 & 2,6465 & 2,64183 \\
\hline Ireland & 377 & ,00 & 7,00 & 3,9469 & 2,23425 \\
\hline Latvia & 312 & 00 & 7,00 & 3,8846 & 2,81124 \\
\hline Lithuania & 347 & 00 & 7,00 & 4,4294 & 2,38554 \\
\hline Luxembourg & 109 &, 00 & 7,00 & 3,1468 & 2,46015 \\
\hline Malta & 91 &, 00 & 7,00 & 3,6374 & 2,30225 \\
\hline \begin{tabular}{|l|} 
Netherlands \\
\end{tabular} & 361 &, 00 & 7,00 & 3,6648 & 2,73275 \\
\hline Norway & 361 &, 00 & 7,00 & 3,9169 & 2,26906 \\
\hline Portugal & 370 &, 00 & 7,00 & 3,5865 & 2,60380 \\
\hline Romania & 405 &, 00 & 7,00 & 4,6568 & 2,40013 \\
\hline Slovakia & 336 &, 00 & 7,00 & 4,2173 & 2,49006 \\
\hline Slovenia & 370 &, 00 & 7,00 & 3,2676 & 2,43646 \\
\hline Sweden & 347 & ,00 & 7,00 & 3,9135 & 2,07476 \\
\hline Turkey & 362 &, 00 & 7,00 & 5,7707 & 2,00136 \\
\hline Croatia & 252 &, 00 & 7,00 & 5,7500 & 1,59587 \\
\hline
\end{tabular}

Tab. 1. Descriptive statistics for the index of the efficiency of ebusiness by countries

\section{RESEARCH RESULTS}

Table 2 shows the indices of efficiency of e-business divided by the Accounting Information System usage. According to the results of a research, 6733 companies use Accounting Information Systems in their business. Looking at the positive indices of efficiency of ebusiness there is a positive trend of increasing number of companies with the growth of index.

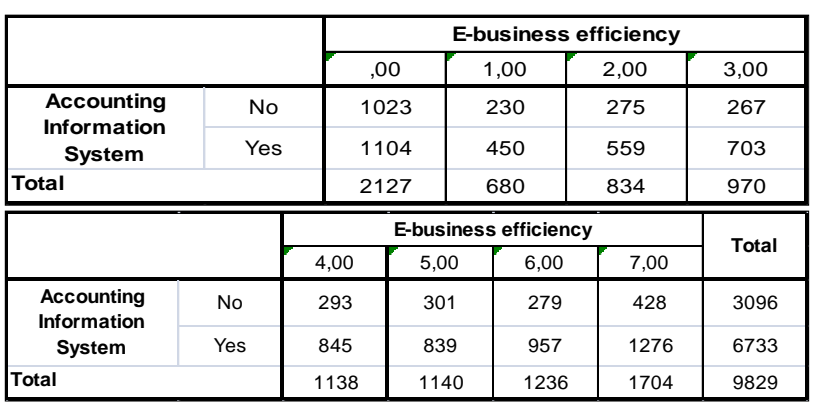

Tab. 2. The index of efficiency of e-business companies by Accounting Information System usage

Furthermore the Figure 1 shows the structure of companies in the sample in the Republic of Croatia, 
according to the usage of the Accounting Information System. Vast majority of Croatian companies in the sample, precisely $86 \%$ of them, use Accounting Information System in their business.

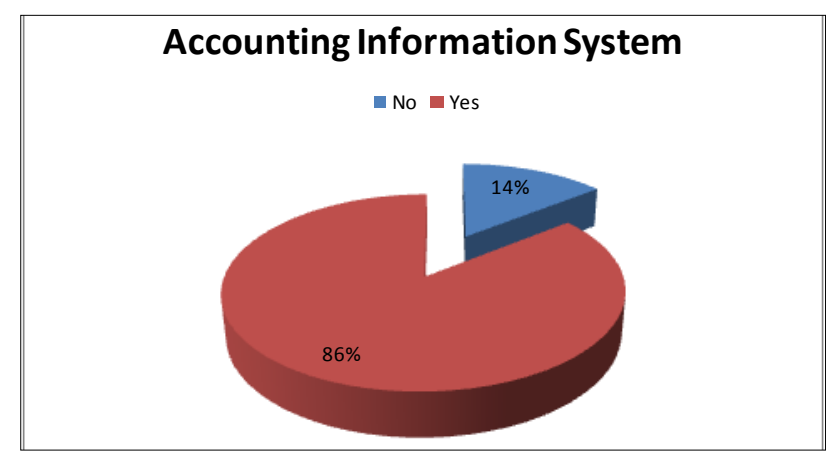

Fig. 1. The structure of companies in the sample that use Accounting Information System where the company operates in Croatia in 2012

The means of indices of efficiency of e-business with regard to the usage of the Accounting Information System in Table 3 vary from 2,88 to 3,85 (on a scale from 0 to 7 ), and the standard deviation from 2,618 to 2,457 .

\begin{tabular}{|l|c|c|c|c|c|}
\hline & $\begin{array}{c}\text { Accounting } \\
\text { Information } \\
\text { System }\end{array}$ & $\mathbf{N}$ & Mean & $\begin{array}{c}\text { Std. } \\
\text { Deviation }\end{array}$ & $\begin{array}{c}\text { Std. Error } \\
\text { Mean }\end{array}$ \\
\hline $\begin{array}{l}\text { E-business } \\
\text { efficiency }\end{array}$ & No & 3096 & 2,88 & 2,618 &, 04705 \\
\cline { 2 - 6 } & Yes & 6733 & 3,85 & 2,457 &, 02995 \\
\hline
\end{tabular}

Tab. 3. Descriptive statistics for the index of the efficiency of ebusiness by usage of the Accounting Information System

\begin{tabular}{|l|c|c|c|}
\hline & Value & df & $\begin{array}{c}\text { Asymp. Sig. } \\
\text { (2-sided) }\end{array}$ \\
\hline Pearson Chi-Square & 390,150 & 7 &, 000 \\
\hline Likelihood Ratio & 377,435 & 7 &, 000 \\
Linear-by-Linear & 305,155 & 1 &, 000 \\
Association & 9829 & & \\
N of Valid Cases & & & \\
\hline
\end{tabular}

Tab. 4. Chi-square test of independence of Accounting Information System usage and the efficiency of e-business of a company

As shown in Table 4, on the significance level of 5\% there is a statistically significant correlation between the Accounting Information System usage and the efficiency of e-business of a company $(p$-value $=0.000)$.

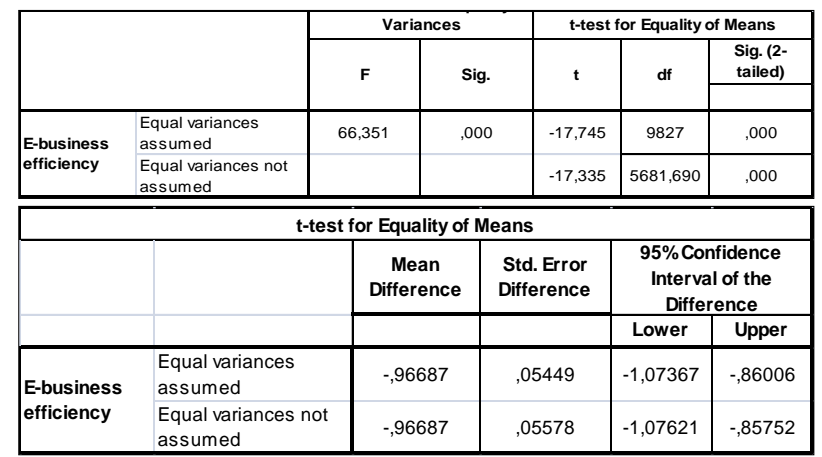

Tab. 5. T-test of arithmetic mean differences two populations for variable Accounting Information System usage

Levene's test of variance equality this two population which shows that variance equality hypothesis are accepted (F-value $=66,351$ and $p$-value=0,000). With these assumption t-test differences of arithmetic means between this two population (for Accounting Information System usage and e-business efficiency) was conducted what can be seen in table 5. It is proved that there are statistically significance correlation between Accounting Information System usage and e-business efficiency with significance level $1 \%$ (p-value $=0,000)$. This empiric research confirms previous researches on importance of Accounting Information Systems.

The importance of Accounting Information Systems as strategic management accounting was noticed in early stages of their development. The idea that accounting information will play an influencing role suggests that, in organizations, management accounting will monitor the long-range performance of the organization in the marketplace and report on the achievements of strategic plans and goals. Therefore, an accounting information system must change its focus from reporting only on product costs to also reporting on the product characteristics that make the product competitive in the marketplace. In addition to collecting and reporting internally generated information, accountants must report on important external information such as market demand for the product being offered, demand and price changes owing to changes in product characteristics and monitor the strategy of each rival competitor. The accounting system can help in measuring and improving productivity because, when properly planned and executed, FMS improves productivity. In the future, accounting information systems will use learning curves to a greater degree to help organizations to understand the link between the firm's product and process [14].

Sanchez-Rodriguez \& Spraakman in their study analyze the changes that ERP implementations have had on (1) performance measures, (2) management accounting techniques, (3) activities of management accountants, and (4) the use of non-financial information. They conclude that the enhanced computing power and overall standardization lead to more accurate and timely information. The standardized transaction processing and the charts of accounts have increased the availability of information from units and products previously deficient of information, and ensured a consistency of information across all units and products. The standardization and automation of transaction processing has reduced the amount of data entry done by management accountants. Performance measures have been standardized, expanded to more units and products, increased in accuracy, and produced more quickly. Management accounting techniques have become more efficient and effective. Management accountants are less involved with data entry, thus allowing them to undertake more analyses and non-financial information is more extensive [15].

Chen et. al. find that the difference of changes of the roles of managerial and non-managerial accountants is the most obvious after ERP implementation. However, past research does not explore this difference from the aspect of different positions. After ERP implementation, the role of non-managerial accountants does not change as much as that of managerial accountants, leader of the e-business project, does. Managerial accountants have to take over more management functions such as education and training and financial analysis. As ERP implementation begins, IT replaces highly repeated traditional accounting operations. Under successful ERP implementations, data quality increases, decision making 
is improved, and the percentage of reports automatically generated by the ERP system is greater. Because of the complete records of transactions and clear audit trail of ERP systems, accountants can utilize the drill down function to track down every transaction in order of general ledgers, sub ledgers and transactions to improve the auditing of the company. This will strengthen its internal control to reinforce its corporate governance [16].

Rom \& Rohde confirmed that ERP systems are powerful tools with regard to transaction processing and integration of the organization, as data collection can be considered a proxy for transaction processing, and organizational breadth of management accounting a proxy for integration. ERP systems have the capability of supporting current management accounting practices. Their conclusion supports the claim that having an ERP system is still better than having no ERP system with regard to the support of the existing management accounting tasks [17].

Abu-Musa investigate empirically the impact of emerging information technology (IT) on internal auditors' activities, and to examine whether the IT evaluations performed in Saudi organizations vary, based on evaluation objectives and organizational characteristics. His results reveal that the internal auditors' performance of IT evaluations is associated with several factors including: the audit objectives, industry type, the number of IT audit specialists on the internal audit staff, and the existence of new Accounting Information Systems [18].

In their results Spathis \& Ananiadis shows that the new ERP system significantly contributes towards increased flexibility in information provision, through effective monitoring and exploitation of the university's assets and revenue-expenditure flow, and improved decision making [19].

\section{CONCLUSION}

E-business is the most frequent form of company business and number of companies which uses this form of business is constantly increasing. There are more different stages of e-business efficiency.

In this paper we investigated the practices by which accounting IS can contribute to the e-business performance. Main objective of this paper was to stress the importance of evolving IS and ICT initiatives in implementing e-business concept. After analyzing ebusiness concept and IS components and elements we explained its connectivity and construct the research model upon the following two hypotheses:

H0: Usage of the Accounting Information System and the efficiency of e-business of a company are statistically independent variables.

H1: Usage of the Accounting Information System and the efficiency of e-business of a company are statistically dependent variables.

We conducted a relevant empiric research which gives the up-to-date information on the impact of Accounting Information System usage on e-business efficiency and made it possible not to reject the hypothesis that indeed Accounting Information System usage affects the e-business efficiency. The results in the paper are limited to only one factor that affects ebusiness. The further analyses should involve deeper analysis of accounting information systems and continue checking for the new factors that might affect e-business in order to recognize the freshest trends and apply it swiftly.

\section{REFERENCES}

[1] Jaković, B. (2012). Impact of Electronic Business Efficency on company Business Results, doctoral dissertation.

[2] Li, F. (2006). What is e-business: How the Internet Transforms Organizations, Wiley-Blackwell; 1 edition, ISBN-13: 978 1405125581 .

[3] Chaffey, D. (2007). E-Business and E-Commerce Management (3rd Edition), Prentice Hall, ISBN-13: 978-0273707523.

[4] McClure, C. R. \& Bertot, J. C. (2000). The Chief Information Officer (CIO): Assessing its impact. Government Information Quarterly, 17, 7-12

[5] Bekkers, V. J. J. M. \& Zouridis, S. (1999). Electronic service delivery in public administration: Some trends and issues. International Review of Administrative Sciences, 65(2), 183-196.

[6] Heeks, R. (2001). Understanding e-governance for development. The University of Manchester, Institute for Development, Policy and Management Information, Systems, Technology and Government: Working Papers Series, Number 11/2001. Available at: http://idpm.man.ac.uk/idpm/igov11abs.htm. Accessed March 22, 2003.

[7] DiCaterino, A. \& Pardo, T. A. (1996). The World Wide Web as a universal interface to government services. Available at: http://www.ctg.albany.edu/resources/abstract/itt96-2.html. Accessed May 10, 2003.

[8] Layne, K. \& Lee, J. (2001). Developing fully functional egovernment: A four stage model. Government Information Quarterly, 18, 122-136.

[9] McGregor, E. B., Jr. (2001). Web page accountability: The case of public schools. Paper presented at the National Public Management Research Conference, Bloomington, IN.

[10] Spremić, M. (2009). IT Governance Mechanisms in Managing IT Business Value, WSEAS Transactions on Information Science and Applications, Issue 6, Volume 6, June 2009, pp. 906-915.

[11] Spremić, M.; Strugar, I. (2002). Strategic Information System Planning in Croatia: Organizational and Managerial Challenges, International Journal of Accounting Information Systems, Vol. 3, Num. 3, pp. 183-200.

[12] Spremić, M. (2012). Measuring IT Governance Performance: A Research Study on CobiT- Based Regulation Framework Usage, International Journal of Mathematics and Computers in Simulation, Volume 1, Issue 6, pp. 17-25, ISSN: 1998-0159.

[13] Ward, J., Peppard, J. (2002). Strategic Planning for Information Systems, $3^{\text {rd }}$ ed., John Wiley \& Sons.

[14] Sriram, R. S. (1995). Accounting information system issues of FMS, Integrated Manufacturing Systems, Vol. 6 Iss: 1 pp. 35 - 40

[15] Sanchez-Rodriguez, C. \& Spraakman, G. (2012). ERP systems and management accounting: A multiple case study, Qualitative Research in Accounting \& Management, Vol. 9 Iss: 4

[16] Chen, H-J.; Huang, S. Y.; Chiu, A-A \& Pai, F-C. (2012). The ERP system impact on the role of accountants, Industrial Management \& Data Systems, Vol. 112 Iss: 1 pp. 83 - 101

[17] Rom, A. \& Rohde, C. (2006). Enterprise resource planning systems, strategic enterprise management systems and management accounting: A Danish study, Journal of Enterprise Information Management, Vol. 19 Iss: 1 pp. $50-66$

[18] Abu-Musa, A. A. (2008). Information technology and its implications for internal auditing: An empirical study of Saudi organizations, Managerial Auditing Journal, Vol. 23 Iss: 5 pp. $438-466$

[19] Spathis, C. \& Ananiadis, J. (2005). Assessing the benefits of using an enterprise system in accounting information and management, Journal of Enterprise Information Management, Vol. 18 Iss: 2 pp. 195 - 210 